\title{
Economic Freedom and People's Regard for Education
}

\author{
Horst Feldmann ${ }^{1}$ (D)
}

Accepted: 5 November 2020 / Published online: 24 November 2020

(c) The Author(s) 2020

\begin{abstract}
Using data on 48 countries, this paper finds that people in economically freer countries care more about education. This is probably mainly because economic freedom enables them and their children to achieve higher returns to education. The magnitude of the estimated effect is substantial. The paper combines individual-level data from the World Values Survey with country-level data on economic freedom and other relevant factors. It controls for all relevant characteristics of survey respondents as well as for potentially confounding country-level characteristics. It also addresses potential endogeneity of economic freedom.
\end{abstract}

Keywords Economic freedom $\cdot$ Education $\cdot$ Schooling $\cdot$ Values

\section{Introduction}

As has long been recognized, education is beneficial to both the individual and society. However, in order to realize its benefits, it is essential that people appreciate education. Indeed, many empirical studies suggest that parents' and students' views of education are of crucial importance for their educational investments and achievements (e.g., HooverDempsey and Sandler 1997; Croll et al. 2008). The success of educational initiatives by governments also depends on a supportive attitude among their populations.

So what determines people's educational views? This paper argues that one important factor might be the degree of economic freedom. Using data on 48 countries, it presents evidence that people's emphasis on and appreciation of education is stronger in countries characterized by more economic freedom. This finding is novel. Although numerous empirical papers analyze a wide array of effects of economic freedom (for a survey, see Hall and Lawson 2014), none analyzes its effects on people's attitudes toward education. Equally, although several papers study how people's personal characteristics affect their educational attitudes (see below), none of them takes economic freedom or other national characteristics into account. We undertake a first attempt to fill this gap.

Our paper is organized in the following way. The next section argues theoretically why individual regard for education can be expected to be stronger in economically freer countries. It also briefly surveys the previous empirical research that is related to our paper.

Horst Feldmann

h.feldmann@bath.ac.uk

1 Department of Economics, University of Bath, Bath BA2 7AY, UK 
Section 3 explains our data and methodology. Section 4 presents and discusses our regression results. Section 5 concludes.

\section{Theoretical Considerations and Related Empirical Research}

There are several reasons why people in economically freer countries can be expected to attach more importance to education. To start with, a modest level of taxation, a key element of economic freedom, implies that individuals are able to achieve comparatively high net returns to education. Monetary stability, another element of economic freedom, ensures that individuals' returns to education are not diluted by inflation. A pro-competitive regulation of labor markets, yet another element, is also likely to foster the importance people attach to education because open labor markets enable individuals to enter professions where their educational returns are the highest. ${ }^{1}$

The elements mentioned so far operate jointly with two further elements of economic freedom-secure property rights and the rule of law. These elements not only prevent the state from expropriating people's earnings, they additionally ensure that the tax system, labor markets as well as the rest of the state and the economy function in a predictable way and protect individuals' returns to education.

Furthermore, economic freedom is likely to increase people's regard for education because it facilitates the operation of credit markets. Elements of economic freedom relevant here are secure property rights (including an effective protection of investors and the right to use property as collateral) and a pro-competitive regulation of those markets. Investment in schooling entails a large upfront fixed cost while the return in form of higher wages accrues throughout working life. Thus parents often need to take out loans to invest in their children's education. The easier it is to use property as collateral and the more competitive credit markets are, the easier and cheaper it is for them to do so. This is likely to increase the importance parents attach to education.

A light regulatory burden on product markets and low barriers to international trade, two further elements of economic freedom, are important because they foster specialization and economic exchange, enhancing the gains from educational investments as well. Of course, the elements mentioned in previous paragraphs also contribute to specialization and economic exchange. These include the rule of law, secure property rights, modest taxation and open labor markets. Monetary stability is important too because it prevents high inflation, which would distort price signals. By fostering specialization and economic exchange, economic freedom increases incomes and returns to education, which in turn probably makes people attach more importance to education.

Economic freedom is likely to strengthen people's regard for education not only among high and middle income households but among low income households as well. Two elements are particularly important to them. First, by facilitating the operation of credit markets economic freedom can increase the availability of loans for educational investments, which are particularly important for low income households. Second, open labor markets enable members from such households to get into professions they may frequently find

\footnotetext{
1 As there are no previous papers about the effect of economic freedom on educational attitudes and only one empirical paper about its effect on returns to education (King et al. 2012), we have developed the theoretical considerations presented in this section without recourse to any specific literature.
} 
hard to enter. Of course, low income households also benefit from the other elements of economic freedom, be it monetary stability or the rule of law, for example.

Finally, economic freedom can increase people's regard for education by leading to better schools. As it implies a comparatively small government sector, market-friendly regulation and openness, including openness to foreign competition, it can enable and stimulate the market entry and growth of private schools, including some run by foreign providers. Competition by private schools can favorably affect both the quantity and the quality of education children receive. This in turn probably improves their occupational opportunities and thus their returns to education. Both the improvement in educational provision as such and the increase in educational returns that it is likely to entail will probably raise the value parents and pupils place on education.

All of these theoretical considerations lead us to hypothesize that individual emphasis on and appreciation of education is stronger in countries characterized by more economic freedom. Although our hypothesis sounds plausible, it has not been tested before. There is some related empirical literature though. For example, using data on 86 developing countries from the period 1989 to 2007, King et al. (2012) find that returns to schooling are substantially higher in economically free countries. Using data from 1972 to 2011 on 109 countries, Feldmann (2017) reports that economic freedom has a strong positive effect on the secondary school enrollment rate.

Other empirical research analyzes the strong growth in private schooling that has taken place in many developing countries over recent decades. It finds that this growth is due to the fact that both teaching and learning outcomes are generally better in private schools than in state schools (e.g., Day Ashley et al. 2014). Parents in developing countries increasingly send their children to private schools, although these charge fees whereas state schools normally do not (e.g., Tooley 2013). Clearly, in developing countries that have allowed the entry and expansion of private providers most parents attach great importance to education.

A different strand of the empirical literature analyzes how personal characteristics affect people's regard for education. Almost all of these papers look at a few characteristics only though. Examples of characteristics studied include educational attainment (e.g., DavisKean 2005), income (e.g., Hastings et al. 2006), social class (e.g., Gorman 1998) and political position (e.g., Fladmoe 2012). A further drawback of these papers is that almost all use small, nationally unrepresentative samples, in most cases from a single country. By contrast, our paper not only covers a fairly large number of countries. Moreover, its individuallevel data, coming from the World Values Survey, are nationally representative (Inglehart et al. 2015). ${ }^{2}$

Finally, our paper is related to the nascent literature that empirically studies the effects of economic freedom on individual values. For example, using data on 69 countries from 2000 and 2005 Berggren and Nilsson (2013) find economic freedom to be positively related to tolerance. Using data on 52 countries from 1995 and 2000, Berggren and Jordahl (2006) find evidence that economic freedom increases social trust. Teague et al. (2020), who use data from 1990, 1995 and 2000-2014, report that people in countries with more economic freedom are less materialistic.

\footnotetext{
2 In a companion paper, we use World Values Survey data to study how personal characteristics affect educational attitudes (Feldmann 2020). This paper does not take economic freedom into account though.
} 


\section{Data and Methodology}

\subsection{Dependent Variables}

To measure the importance respondents attached to education, we use two dummy variables (for definitions and descriptive statistics of all variables, see "Appendix 1"). The first equals one if a respondent selected as their first choice "inadequate education" as the most serious problem for their own country. The alternatives were: "people living in poverty and need", "discrimination against girls and women", "poor sanitation and infectious diseases" and "environmental pollution". This question was included in wave 5 (2005-2009) of the World Values Survey (Inglehart et al. 2015).

A major plus of the question is that it requires respondents to make trade-offs, as is the case with all real choices. In surveys that do not require this, virtually all respondentsparents and students alike-normally acknowledge the importance of education (e.g., Croll et al. 2008; Spera et al. 2009). In such surveys, they may feel compelled to give socially desirable responses, especially in societies that have traditionally held education in high regard (Jacob and Lefgren 2007).

Our second dependent variable equals one if a respondent said that they worried very much or a great deal about "not being able to give my children a good education". It equals zero if they said that they worried about this not much or not at all. This question was included in wave 6 (2010-2014) of the World Values Survey (Inglehart et al. 2015).

Interestingly, the second question, which is more personal than the first, has by far the highest share of respondents agreeing with it: no less than $71 \%$ were worried about their children's education. By contrast, only $12 \%$ selected inadequate education as the most serious problem for their own country.

Note that the answers to both questions do not exclusively reflect the value respondents placed on education. They also reflect the quality of the national school systems and, as far as the second question is concerned, income levels. Fortunately, we are able to control for these confounding influences at least to some degree. We do so in three ways. First, we include among our explanatory variables 'income' and, in one robustness check, 'GDP per capita' (Sect. 3.2). Second, we use country dummies, which capture the time-invariant dimensions of both the quality of national school systems and the level of economic development (Sect. 3.3). Third, we explore the quality of national school systems in Sect. 4.2.

\subsection{Explanatory Variables}

Our measure of economic freedom comes from the "Economic Freedom of the World (EFW)" index (Gwartney et al. 2019). This is the most widely used index of economic freedom and is generally considered to be the best because it covers all major aspects of economic freedom, uses data from reputable external sources (such as the World Bank and the IMF), almost exclusively relies on hard data and covers a large number of countries. ${ }^{3}$ The EFW index incorporates 43 distinct variables that are organized into five areas: size of government, legal system and property rights, sound money, freedom to trade internationally, and regulation of credit, labor and business. The summary ratings of the index are the

\footnotetext{
3 By contrast, the Heritage Foundation's "Index of Economic Freedom" partly relies on subjective assessments of in-house experts (Miller et al. 2020).
} 
arithmetic means of the area ratings. We use these summary ratings rather than the area ratings because, as explained in Sect. 2, the various elements of economic freedom are interrelated and likely to jointly affect both returns to and attitudes toward education. The summary ratings used are adjusted to account for the fact that the number and composition of the components have changed over time as the index has become more comprehensive and available data more complete. The adjusted ratings are consistent both across countries and through time.

To separate out the impact of economic freedom from other potentially confounding factors, we control for a large number of characteristics of respondents. Using World Values Survey data (Inglehart et al. 2015), we cover not only standard demographic characteristics but also social characteristics and respondents' values, in so far as these are potentially relevant here. More specifically, we include controls for educational attainment, household income (relative to national income), social class, political position, postmaterialist value orientation, religion (adherence and religiosity), gender, age, ethnicity, health, marital status, number of children, family value orientation, employment status and size of respondent's town. As indicated in Sect. 2, several of these characteristics affect people's attitudes toward education. Examples include educational attainment, income, social class, political position and religion.

In addition to these baseline controls, we also use several further control variables, most of which we add in robustness checks. As already mentioned in Sect. 3.1, one such control is 'GDP per capita' (Feenstra et al. 2019). We use it for two reasons. First, we need to ensure that economic freedom does not proxy for GDP per capita, given that most richer countries have more economic freedom. Second, people's preferences for education could vary with the level of economic development of their own country. In another robustness check, we add the country-level variable 'democracy', which ranges from strongly autocratic to strongly democratic (Marshall et al. 2017). In a further robustness check, we add a variable measuring countries' extent of civil liberties (Freedom House 2019). In yet another check, we add a World Values Survey variable that measures how much freedom of choice and control respondents feel to have over their lives. We use these three measures of freedom for similar reasons as GDP per capita-first, to ensure that economic freedom does not proxy for them and second, to check whether some of these measures exert an influence of their own on people's educational attitudes. ${ }^{4}$

In our final robustness check, we add a measure of credit availability: 'private credit'. According to a large literature, credit constraints can prevent the poor from investing in education (e.g., Galor and Zeira 1993, De Gregorio 1996). Based on this literature, we hypothesize that a better availability of credit might increase people's focus on and appreciation of education. ${ }^{5}$

On top of our robustness checks, we explore interaction effects. In one such exercise, we study the links between social trust, economic freedom and appreciation of education. A literature since Coleman's (1988) seminal paper finds social capital (usually proxied by social trust) to positively affect educational performance (for a survey, see Acar 2011). We analyze both whether social trust directly affects regard for education and whether the effect of economic freedom on regard for education varies with the level of social trust.

\footnotetext{
${ }^{4}$ For a discussion and comparison of various measures of freedom, see Okulicz-Kozaryn (2014).

5 Note that credit availability is related to, but distinct from the regulation of credit markets, an element of economic freedom (Sects. 2 and 3.2). Whereas credit market regulation is an institution, credit availability is an outcome.
} 


\subsection{Econometric Specification}

In our baseline specification, we estimate the following probit model:

$$
Y_{j, i, t}=\alpha+\beta X_{i, t}+\sum_{k=1}^{r} \gamma_{k} Z_{k, j, i, t}+\delta_{i}+\varepsilon_{j, i, t}
$$

$Y_{j, i, t}$ denotes one of our two dummy variables measuring regard for education by individual $j$ in country $i$ and survey year $t$. $X_{i, t}$ denotes 'economic freedom', a country-level variable. $Z_{k, j, i, t}$ denotes a vector of $r$ individual-level control variables. While $\alpha$ is the constant, $\delta_{i}$ represents country dummies. Finally, $\varepsilon_{j, i, t}$ denotes the error term.

Throughout, we exclude respondents below the age of 25 . We do so in order to account for potential reverse causality from educational views to educational attainment. For example, those who hold education in high regard may acquire more of it. As almost everybody aged 25 and above has completed their education, we avoid any such reverse causality bias.

We also account for potential endogeneity of 'economic freedom'. For example, people who hold education in high regard may also be in favor of economic freedom and may thus support politicians who promise more of it. This reasoning is akin to Lipset (1960), who believed that educated people are more likely to resolve their differences through courts, negotiations and voting, rather than through violence. They would thus build "good" legal and political institutions. We account for potential endogeneity of 'economic freedom' in two ways. First, we run a Wald test that tests the null hypothesis that 'economic freedom' is exogenous. As the results from this test indicate, we cannot reject the null-neither when using our first nor when using our second dependent variable (Table 1). This suggests that it is appropriate not to instrument our variable of interest. Our second way to account for potential endogeneity of 'economic freedom' is to lag it by 5 years in a further robustness check.

Although we take potential endogeneity of 'economic freedom' into account to some degree, the regression analysis presented below does not establish causality. Instead, the regressions are used to measure conditional correlations-i.e., to assess whether 'economic freedom' is statistically significant after controlling for other relevant factors. Still, the estimates for our variable of interest are likely to be causal for five reasons. First, we control for a large number of characteristics of respondents, several of which are likely to affect educational attitudes. Second, we also control for unobserved country effects. Third, we ensure that 'economic freedom' does not proxy for other types of freedom, GDP per capita or credit availability. Fourth, in one robustness check we lag 'economic freedom' by 5 years. Fifth, the results from the Wald test of exogeneity do not provide evidence of endogeneity.

\section{Results and Discussion}

\subsection{Regression Results}

Tables 1, 2, 3 and 4 report average marginal effects of our probit regressions. Whereas Table 1 reports the results from the baseline specification, Tables 2 and 3 report the results from our robustness checks. Table 4 reports results from regressions in which we add interaction terms. For brevity, the estimates for the control variables are omitted in Tables 2, 
Table 1 Main estimates

(1)

Inadequate education most serious problem for their own country
(2)

Worried about not being able to give their children a good education

\begin{tabular}{|c|c|c|}
\hline Economic freedom & $\begin{array}{l}0.529 * * * \\
(0.179)\end{array}$ & $\begin{array}{l}0.419 * * * \\
(0.114)\end{array}$ \\
\hline Elementary education & $\begin{array}{c}0.019 \\
(0.012)\end{array}$ & $\begin{array}{c}0.022 \\
(0.019)\end{array}$ \\
\hline Middle education & $\begin{array}{l}0.036^{* * *} \\
(0.015)\end{array}$ & $\begin{array}{c}0.021 \\
(0.015)\end{array}$ \\
\hline Higher education & $\begin{array}{l}0.053^{* * *} \\
(0.016)\end{array}$ & $\begin{array}{r}-0.000 \\
(0.016)\end{array}$ \\
\hline Income & $\begin{array}{l}0.005^{* * * *} \\
(0.001)\end{array}$ & $\begin{array}{c}-0.011 * * * \\
(0.003)\end{array}$ \\
\hline Middle class & $\begin{array}{c}0.005 \\
(0.009)\end{array}$ & $\begin{array}{r}-0.003 \\
(0.013)\end{array}$ \\
\hline Upper class & $\begin{array}{r}-0.003 \\
(0.021)\end{array}$ & $\begin{array}{c}-0.058 * * \\
(0.023)\end{array}$ \\
\hline Political left & $\begin{array}{r}-0.002 \\
(0.013)\end{array}$ & $\begin{array}{r}-0.004 \\
(0.010)\end{array}$ \\
\hline Political right & $\begin{array}{c}0.000 \\
(0.013)\end{array}$ & $\begin{array}{c}0.010 \\
(0.010)\end{array}$ \\
\hline Postmaterialist & $\begin{array}{l}0.049^{* * * *} \\
(0.018)\end{array}$ & $\begin{array}{r}-0.007 \\
(0.015)\end{array}$ \\
\hline Protestant & $\begin{array}{c}-0.020 * * \\
(0.009)\end{array}$ & $\begin{array}{c}0.006 \\
(0.020)\end{array}$ \\
\hline Roman Catholic & $\begin{array}{r}-0.009 \\
(0.010)\end{array}$ & $\begin{array}{c}0.008 \\
(0.021)\end{array}$ \\
\hline Eastern Orthodox & $\begin{array}{r}-0.014 \\
(0.018)\end{array}$ & $\begin{array}{c}0.014 \\
(0.019)\end{array}$ \\
\hline Other Christian & $\begin{array}{c}-0.032 * * * \\
(0.012)\end{array}$ & $\begin{array}{r}-0.009 \\
(0.023)\end{array}$ \\
\hline Jewish & $\begin{array}{c}0.029 \\
(0.054)\end{array}$ & $\begin{array}{l}0.205^{* * * *} \\
(0.045)\end{array}$ \\
\hline Muslim & $\begin{array}{r}-0.023 \\
(0.017)\end{array}$ & $\begin{array}{c}0.035 \\
(0.029)\end{array}$ \\
\hline Hindu & $\begin{array}{r}-0.002 \\
(0.022)\end{array}$ & $\begin{array}{r}-0.042 \\
(0.032)\end{array}$ \\
\hline Buddhist & $\begin{array}{r}-0.002 \\
(0.020)\end{array}$ & $\begin{array}{r}-0.009 \\
(0.035)\end{array}$ \\
\hline Other Eastern religions & $\begin{array}{c}0.020 \\
(0.023)\end{array}$ & $\begin{array}{c}0.102 \\
(0.238)\end{array}$ \\
\hline Other religions & $\begin{array}{r}-0.002 \\
(0.017)\end{array}$ & $\begin{array}{c}0.008 \\
(0.017)\end{array}$ \\
\hline God important & $\begin{array}{c}0.002 \\
(0.002)\end{array}$ & $\begin{array}{c}0.003 \\
(0.003)\end{array}$ \\
\hline Female & $\begin{array}{c}-0.020 * * * \\
(0.006)\end{array}$ & $\begin{array}{c}0.011 * \\
(0.006)\end{array}$ \\
\hline Age & $\begin{array}{c}-0.003^{* *} * \\
(0.002)\end{array}$ & $\begin{array}{c}0.000 \\
(0.001)\end{array}$ \\
\hline
\end{tabular}


Table 1 (continued)

(1)

Inadequate education most serious problem for their own country
(2)

Worried about not being able to give their children a good education

\begin{tabular}{|c|c|c|}
\hline $\mathrm{Age}^{2}$ & $\begin{array}{c}0.000 \\
(0.000)\end{array}$ & $\begin{array}{c}-0.000 * * * \\
(0.000)\end{array}$ \\
\hline White & $\begin{array}{c}0.005 \\
(0.008)\end{array}$ & $\begin{array}{c}-0.052 * * * \\
(0.016)\end{array}$ \\
\hline Black & $\begin{array}{c}0.007 \\
(0.020)\end{array}$ & $\begin{array}{l}0.061 * * * \\
(0.014)\end{array}$ \\
\hline East Asian & $\begin{array}{c}0.038 \\
(0.028)\end{array}$ & $\begin{array}{l}0.113 * * \\
(0.047)\end{array}$ \\
\hline Other Asian or Arab & $\begin{array}{c}0.002 \\
(0.023)\end{array}$ & $\begin{array}{r}-0.011 \\
(0.033)\end{array}$ \\
\hline Health & $\begin{array}{r}-0.005 \\
(0.003)\end{array}$ & $\begin{array}{r}-0.007 \\
(0.005)\end{array}$ \\
\hline Married & $\begin{array}{r}-0.005 \\
(0.009)\end{array}$ & $\begin{array}{l}0.075^{* * * *} \\
(0.012)\end{array}$ \\
\hline Living together & $\begin{array}{r}-0.018 \\
(0.017)\end{array}$ & $\begin{array}{l}0.052 * * * \\
(0.015)\end{array}$ \\
\hline Divorced & $\begin{array}{l}0.022 * \\
(0.013)\end{array}$ & $\begin{array}{l}0.038 * \\
(0.020)\end{array}$ \\
\hline Separated & $\begin{array}{c}0.008 \\
(0.018)\end{array}$ & $\begin{array}{l}0.068 * * * \\
(0.021)\end{array}$ \\
\hline Widowed & $\begin{array}{c}0.006 \\
(0.017)\end{array}$ & $\begin{array}{c}0.023 \\
(0.017)\end{array}$ \\
\hline Children & $\begin{array}{c}0.002 \\
(0.002)\end{array}$ & $\begin{array}{l}0.013 * * * \\
(0.003)\end{array}$ \\
\hline Family important & $\begin{array}{c}0.041 \\
(0.029)\end{array}$ & $\begin{array}{l}0.054^{*} \\
(0.032)\end{array}$ \\
\hline Employed & $\begin{array}{r}-0.000 \\
(0.009)\end{array}$ & $\begin{array}{l}0.029 * * * \\
(0.008)\end{array}$ \\
\hline Unemployed & $\begin{array}{r}-0.016 \\
(0.012)\end{array}$ & $\begin{array}{l}0.041 * * * \\
(0.011)\end{array}$ \\
\hline Town & $\begin{array}{c}0.003^{*} \\
(0.002)\end{array}$ & $\begin{array}{r}-0.000 \\
(0.002)\end{array}$ \\
\hline Number of observations & 14,999 & 26,222 \\
\hline Number of countries & 24 & 33 \\
\hline \multicolumn{3}{|l|}{ Pseudo $R^{2}$} \\
\hline McFadden & 0.05 & 0.21 \\
\hline McKelvey and Zavoina & 0.10 & 0.36 \\
\hline $\begin{array}{l}\text { Wald test of exogeneity } \\
\text { ( } p \text { value) }\end{array}$ & 0.59 & 0.23 \\
\hline
\end{tabular}

Average marginal effects of probit regressions. Both regressions additionally include country dummies and a constant term. While the World Values Survey (WVS) data used in regression 1 are from wave 5 (20052009), the WVS data used in regression 2 are from wave 6 (2010-2014) (Inglehart et al. 2015). The 'economic freedom' data are from Gwartney et al. (2019). The Wald test of exogeneity tests the null hypothesis that 'economic freedom' is exogenous. Robust standard errors, adjusted for clustering at the country level, are reported in parentheses. $* * *(* * / *)$ denotes statistically significant at the $1 \%(5 \% / 10 \%)$ level 


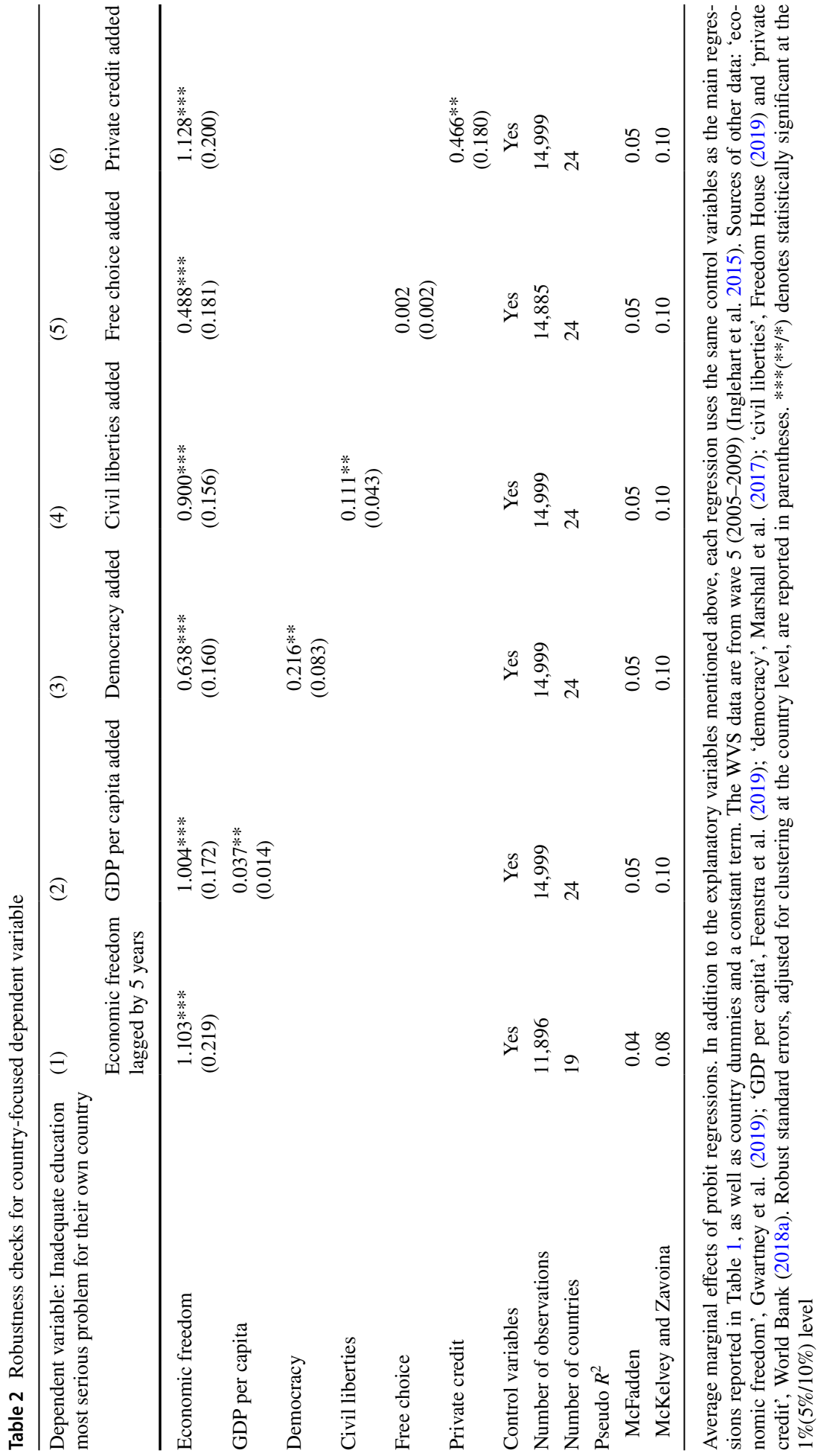




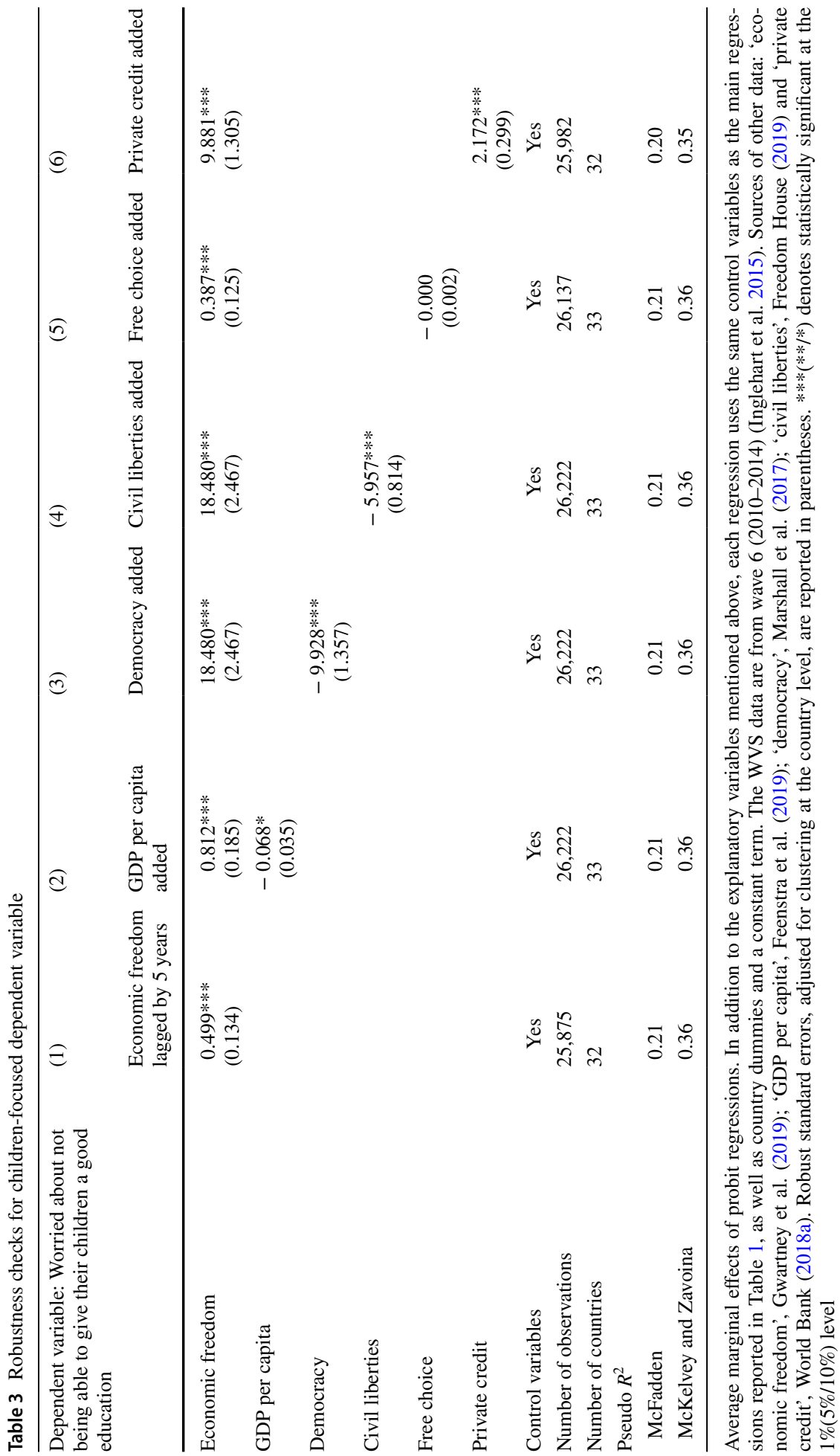


Table 4 Interaction terms added

\begin{tabular}{|c|c|c|c|c|}
\hline & (1) & (2) & (3) & (4) \\
\hline & \multicolumn{2}{|c|}{$\begin{array}{l}\text { Inadequate education most } \\
\text { serious problem for their } \\
\text { own country }\end{array}$} & \multicolumn{2}{|c|}{$\begin{array}{l}\text { Worried about not being able } \\
\text { to give their children a good } \\
\text { education }\end{array}$} \\
\hline & $\begin{array}{l}\text { Educational } \\
\text { attainment }\end{array}$ & Social trust & $\begin{array}{l}\text { Educational } \\
\text { attainment }\end{array}$ & Social trust \\
\hline Economic freedom & $\begin{array}{l}0.532 * * \\
(0.240)\end{array}$ & $\begin{array}{l}0.565^{* *} \\
(0.220)\end{array}$ & $\begin{array}{l}0.651^{* * * *} \\
(0.185)\end{array}$ & $\begin{array}{l}0.455^{* * *} \\
(0.118)\end{array}$ \\
\hline Elementary education & $\begin{array}{c}0.093 \\
(0.102)\end{array}$ & & $\begin{array}{c}0.190 \\
(0.183)\end{array}$ & \\
\hline Middle education & $\begin{array}{c}0.019 \\
(0.144)\end{array}$ & & $\begin{array}{c}0.128 \\
(0.105)\end{array}$ & \\
\hline Higher education & $\begin{array}{c}0.061 \\
(0.135)\end{array}$ & & $\begin{array}{l}0.308^{* * * *} \\
(0.115)\end{array}$ & \\
\hline $\begin{array}{l}\text { Economic freedom } \times \text { Elementary educa- } \\
\text { tion }\end{array}$ & $\begin{array}{r}-0.109 \\
(0.150)\end{array}$ & & $\begin{array}{r}-0.254 \\
(0.265)\end{array}$ & \\
\hline Economic freedom $\times$ Middle education & $\begin{array}{c}0.025 \\
(0.200)\end{array}$ & & $\begin{array}{r}-0.165 \\
(0.158)\end{array}$ & \\
\hline Economic freedom $\times$ Higher education & $\begin{array}{r}-0.011 \\
(0.189)\end{array}$ & & $\begin{array}{l}-0.454 * * * \\
(0.165)\end{array}$ & \\
\hline Social trust & & $\begin{array}{c}0.015 \\
(0.070)\end{array}$ & & $\begin{array}{l}0.205^{* *} \\
(0.103)\end{array}$ \\
\hline Economic freedom $\times$ Social trust & & $\begin{array}{r}-0.037 \\
(0.092)\end{array}$ & & $\begin{array}{l}-0.331 * * \\
(0.144)\end{array}$ \\
\hline Control variables & Yes & Yes & Yes & Yes \\
\hline Number of observations & 14,999 & 14,443 & 26,222 & 25,826 \\
\hline Number of countries & 24 & 24 & 33 & 33 \\
\hline \multicolumn{5}{|l|}{ Pseudo $R^{2}$} \\
\hline McFadden & 0.05 & 0.05 & 0.21 & 0.21 \\
\hline McKelvey and Zavoina & 0.10 & 0.10 & 0.36 & 0.36 \\
\hline
\end{tabular}

Average marginal effects of probit regressions. Dependent variables: 'Inadequate education most serious problem for their own country' (columns 1 and 2) and 'Worried about not being able to give their children a good education' (columns 3 and 4). In addition to the explanatory variables mentioned above, each regression uses the same control variables as the main regressions reported in Table 1, as well as country dummies and a constant term. While the WVS data used in columns 1 and 2 are from wave 5 (2005-2009), the WVS data used in columns 3 and 4 are from wave 6 (2010-2014) (Inglehart et al. 2015). The "economic freedom' data are from Gwartney et al. (2019). Robust standard errors, adjusted for clustering at the country level, are reported in parentheses. $* * *(* * / *)$ denotes statistically significant at the $1 \%(5 \% / 10 \%)$ level

3 and 4 . Each of the regressions in these tables additionally uses the same controls as the baseline regressions of Table $1 .^{6}$

Tables 1, 2, 3 and 4 also report two goodness-of-fit measures. The first is the most commonly used Pseudo $R^{2}$ constructed by McFadden (1973). As this measure has been found

\footnotetext{
${ }^{6}$ The total number of countries covered by the World Values Survey (WVS) was 54 in wave 5 and 60 in wave 6. In our regressions, the number of countries is much lower due to limited data availability, both for 'economic freedom' and, more importantly, for several of the WVS variables. For a list of our countries, see "Appendix 2".
} 
to have a downward bias (e.g., Veall and Zimmermann 1996), we additionally report the Pseudo $R^{2}$ constructed by McKelvey and Zavoina (1975). The latter is often regarded as the best fit measure for limited dependent variable models (e.g., Veall and Zimmermann 1996; Long 1997). It also has the advantage of being most comparable to $R^{2}$ from OLS regressions (e.g., Veall and Zimmermann 1996). Anyhow, in our case both McFadden's as well as McKelvey and Zavoina's Pseudo $R^{2}$ suggest that our model has a good fit when using the second dependent variable. By contrast, the fit is much weaker when using the first dependent variable.

As Table 1 documents, the average marginal effect of 'economic freedom' is positive and statistically highly significant in both of our baseline regressions-i.e., when using the dependent variable that focusses on respondents' own country and when using the dependent variable that focusses on respondents' children. This suggests that, in our sample, respondents in economically freer countries cared more about education. Furthermore, in both cases the magnitude of the estimated effect is substantial. For example, a ten percentage point increase in economic freedom raises the probability that respondents were worried about education in their own country by an average of 5.3 percentage points, ceteris paribus. Furthermore, it raises the probability that they were worried about the education of their children by an average of 4.2 percentage points, ceteris paribus. Of course, these figures should be taken with a grain of salt. Still, they illustrate that the impact of economic freedom on people's regard for education is likely to have been substantial.

Table 2 reports the results from our robustness checks using the country-focused dependent variable, while Table 3 reports the results from the corresponding checks using the children-focused variable. In the first robustness check, we lag 'economic freedom' by 5 years. In the second, we add 'GDP per capita'. In the next three checks, we add our alternative measures of freedom (one at a time): 'democracy', 'civil liberties' and 'free choice' (columns 3-5). Column 6 reports the results from our final robustness check, in which we additionally include 'private credit'.

In each of the six robustness checks, 'economic freedom' is positive and statistically highly significant, confirming the result from our baseline regressions: more economic freedom is likely to have strengthened regard for education. Moreover, the results from the first check are in line with the results from the exogeneity test of Table 1; they suggest that our estimates for 'economic freedom' are unlikely to reflect reverse causality. The results from robustness checks 2 to 5 imply that economic freedom proxies neither for GDP per capita nor for other forms of freedom. The results from our final check suggest that, although economic freedom can increase the availability of credit (Sect. 2), it is not this factor that drives the estimates for our variable of interest. Rather, economic freedom's positive effect on regard for education is independent of credit availability. Interestingly, 'private credit' has a positive effect on both dependent variables too, corroborating our conjecture that a better availability of credit might increase people's focus on and appreciation of education (Sect. 3.2). ${ }^{7}$

In Table 4, which reports interaction effects, columns 1 and 2 document the results for the country-focused dependent variable while columns 3 and 4 document those for the children-focused variable. Whereas our first model includes interactions between 'economic freedom', on the one hand, and our three educational attainment variables, on the

\footnotetext{
7 The magnitude of the estimated effect of 'economic freedom' varies substantially when additionally using other country-level variables. This is probably mainly due to the fact that most of these variables are quite highly correlated with 'economic freedom'.
} 
other, our second model includes 'social trust' and its interaction with 'economic freedom'. In each of the four regressions, the coefficient on 'economic freedom' is positive and statistically highly significant, once again corroborating our main hypothesis. Furthermore, according to the results from regression 3 , respondents with higher education worried more about not being able to give their children a good education but their worries lessened with rising economic freedom. This suggests that this group valued the education of their children particularly highly and that they probably saw more educational opportunities in an environment characterized by more economic freedom.

The results from regression 4 of Table 4 suggest two things. First, respondents who trusted others more attached greater importance to their children's education. This could help to explain the finding of the social capital literature that more social capital generally improves educational performance (Sect. 3.2). Second, the results from regression 4 suggest that the effect of social trust on regard for education fell with rising economic freedom. As more economic freedom usually provides more opportunities for a good education, social trust could become less important for education.

\subsection{Economic Freedom and Educational Quality}

In our discussion of the regression results, we interpret the positive effect of economic freedom on our two dependent variables as reflecting higher regard for education. There is one lingering concern though: Could the positive effect instead reflect that economically freer countries perhaps have a lower quality of education, leading to more worries among respondents? We address this concern in several ways. First, as mentioned previously, we include country dummies in our regressions. Previous research has shown that, in most countries, the quality of national school systems is remarkably stable over time (Hanushek and Woessmann 2015; Woessmann 2016). Therefore, our country dummies control for a major part of educational quality.

However, a limitation of our regression analysis is that it does not directly control for the quality of national school systems. This is due to a lack of internationally comparable data. For most countries included in our sample no such data are available for our sample period. Fortunately, the World Bank (2018b) has recently calculated harmonized test scores from major international student achievement testing programs such as TIMMS (Trends in International Mathematics and Science Study), PIRLS (Progress in International Reading Literacy Study) and PISA (Programme for International Student Assessment). These scores cover a large number of countries and refer to the year 2017. They are the best globally comparable indicators of the quality of national school systems.

Figure 1 plots the harmonized test scores against the economic freedom ratings for 2017. It covers the 48 countries from our regression analysis. The graph shows that there is a positive correlation between economic freedom and test scores, suggesting that, by and large, economically freer countries had better national school systems.

Using the same indicators, Fig. 2 expands the sample from 48 to 137 countries. The message is the same as from Fig. 1: countries with more economic freedom generally had a higher quality of education. Taken together, both graphs dispel the concern that the positive effect of economic freedom estimated in our regression analysis could be due to a lower quality of education in economically freer countries. As the quality of education was not lower but higher, the positive coefficients on economic freedom in our regression analysis clearly reflect increasing regard for education in such countries. Remarkably, in economically freer countries people were more concerned about education in spite of the 


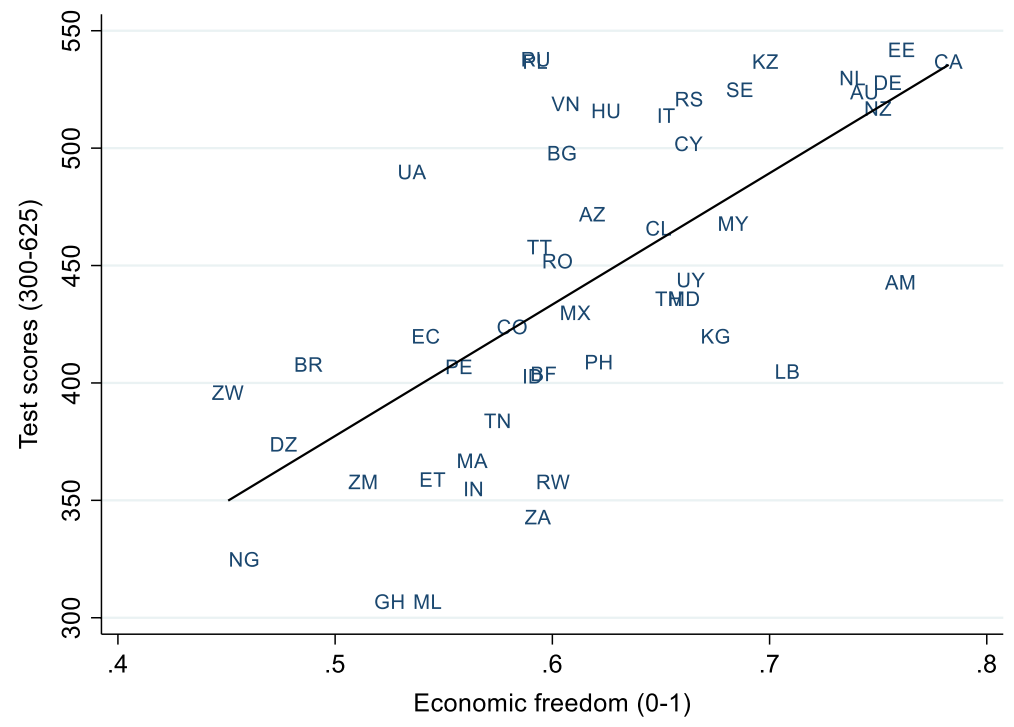

Fig. 1 Economic freedom and test scores: countries included in regression analysis. Note: 48 countries. Data from the year 2017. 'Economic Freedom of the World' adjusted summary ratings, scaled to range from 0 (least free) to 1 (most free). Harmonized test scores from major international student achievement testing programs; the scores are measured in TIMMS-equivalent units, where 300 is minimal attainment and 625 is advanced attainment. The regression represented by the fitted line yields a coefficient on 'economic freedom' of 559.56 (robust standard error=77.62), $N=48, R^{2}=0.44$. Sources: Gwartney et al. (2019), World Bank (2018b)

fact that in most such countries the quality of the national school system was better than in economically less free countries.

\section{Conclusion}

Using data on 48 countries, this paper establishes that, over 2005-2014, people in economically freer countries cared more about education. The magnitude of the estimated effect is substantial. The chief reason for the positive effect probably is that economic freedom enables people to achieve higher returns to education (King et al. 2012). Additionally, it makes it easier to take out loans to finance educational investments. Moreover, economic freedom is likely to improve the quality of schools, which should also strengthen people's regard for education.

Our finding is novel. The effect of economic freedom on people's focus on and appreciation of education has not been studied previously. Thus our paper helps to fill a gap in the literature. In doing so, it also helps to explain Feldmann's (2017) finding that the secondary enrollment rate is substantially higher in economically freer countries: As parents in such 


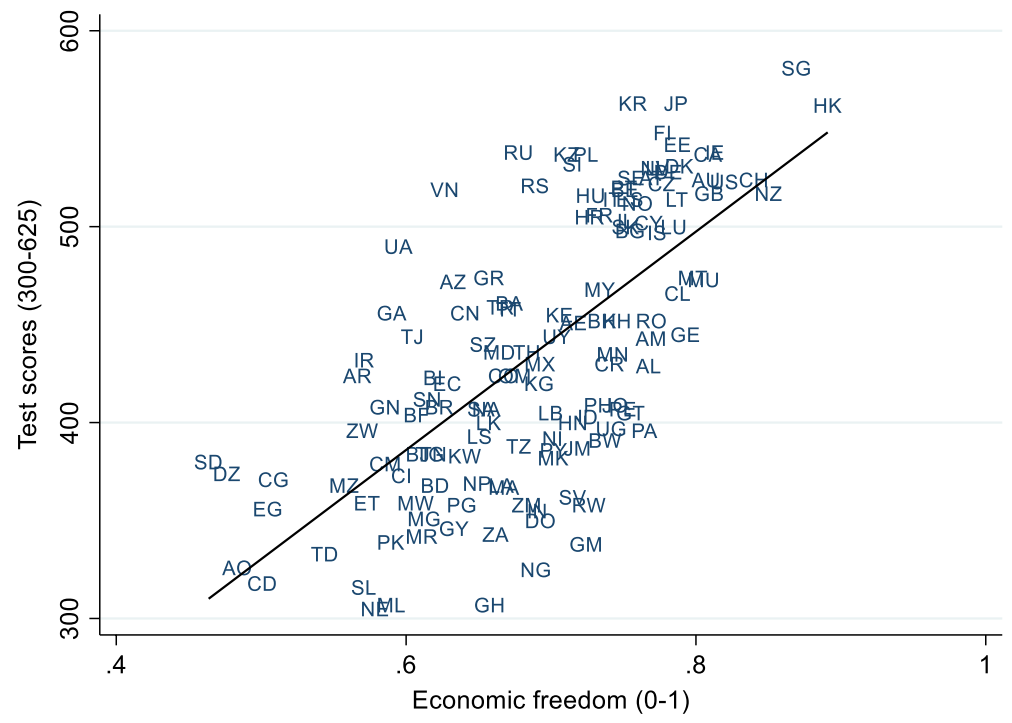

Fig. 2 Economic freedom and test scores: large sample of countries. Note: 137 countries. Data from the year 2017. 'Economic Freedom of the World' adjusted summary ratings, scaled to range from 0 (least free) to 1 (most free). Harmonized test scores from major international student achievement testing programs; the scores are measured in TIMMS-equivalent units, where 300 is minimal attainment and 625 is advanced attainment. The regression represented by the fitted line yields a coefficient on 'economic freedom' of 557.30 (robust standard error $=43.21$ ), $N=137, R^{2}=0.46$. Sources: Gwartney et al. (2019), World Bank (2018b)

countries place a higher value on education, they are probably more inclined to send their children to secondary school. ${ }^{8}$

Although our regressions control for many factors and the results are robust, more research is clearly warranted. Three issues stand out. First, in order to completely rule out endogeneity bias the economic freedom variable should be instrumented. We were unable to do so because of a lack of valid instruments. Second, any future regression analysis should include a control variable measuring the quality of national school systems. Finally, future research should cover both more countries and more recent years.

As education is essential for economic development, a better understanding of the role played by economic freedom is not only important for future research. It is also important for policy-making. Our results suggest that, by enhancing economic freedom, policy-makers could increase people's willingness to invest into their education and into that of their children.

Open Access This article is licensed under a Creative Commons Attribution 4.0 International License, which permits use, sharing, adaptation, distribution and reproduction in any medium or format, as long as you give appropriate credit to the original author(s) and the source, provide a link to the Creative Commons licence, and indicate if changes were made. The images or other third party material in this article

\footnotetext{
${ }^{8}$ As indicated in the main text, our results accord with the most closely related previous research: King et al. (2012) and Feldmann (2017). It is also in line with the research analyzing the growth of private schooling in developing countries (Sect. 2). Moreover, it adds to the literature on the determinants of educational attitudes as well as to the literature documenting that economic freedom can affect individual values.
} 
are included in the article's Creative Commons licence, unless indicated otherwise in a credit line to the material. If material is not included in the article's Creative Commons licence and your intended use is not permitted by statutory regulation or exceeds the permitted use, you will need to obtain permission directly from the copyright holder. To view a copy of this licence, visit http://creativecommons.org/licenses/by/4.0/.

\section{Appendix 1: List of variables}

\begin{tabular}{|c|c|c|c|c|c|}
\hline & Definition & Mean & SD & Min & $\operatorname{Max}$ \\
\hline $\begin{array}{l}\text { Inadequate education most serious } \\
\text { problem for their own country }\end{array}$ & $\begin{array}{l}\text { Dummy variable that equals } 1 \text { if } \\
\text { respondent selected as his first } \\
\text { choice "inadequate education" } \\
\text { as the most serious problem for } \\
\text { his own country. Other answer } \\
\text { categories: "People living in } \\
\text { poverty and need", "Discrimina- } \\
\text { tion against girls and women", } \\
\text { "Poor sanitation and infectious } \\
\text { diseases" and "Environmental } \\
\text { pollution" }\end{array}$ & 0.12 & 0.32 & 0 & 1 \\
\hline $\begin{array}{l}\text { Worried about not being able to } \\
\text { give their children a good educa- } \\
\text { tion }\end{array}$ & $\begin{array}{l}\text { Dummy variable that equals } 1 \text { if } \\
\text { respondent said that he wor- } \\
\text { ried very much or a great deal } \\
\text { about "not being able to give } \\
\text { my children a good education". } \\
\text { It equals } 0 \text { if he said that he } \\
\text { worried about this not much or } \\
\text { not at all }\end{array}$ & 0.71 & 0.46 & 0 & 1 \\
\hline Economic freedom & $\begin{array}{l}\text { 'Economic Freedom of the World' } \\
\text { adjusted summary ratings, } \\
\text { scaled to range from } 0 \text { (least } \\
\text { free) to } 1 \text { (most free). The EFW } \\
\text { index measures the degree of } \\
\text { economic freedom in the follow- } \\
\text { ing five areas: size of govern- } \\
\text { ment, legal system and property } \\
\text { rights, sound money, freedom to } \\
\text { trade internationally, regulation } \\
\text { of credit, labor and business }\end{array}$ & 0.69 & 0.07 & 0.50 & 0.85 \\
\hline \multicolumn{6}{|l|}{$\begin{array}{l}\text { Educational attainment (excluded } \\
\text { category: inadequately completed } \\
\text { elementary education) }\end{array}$} \\
\hline Elementary education & $\begin{array}{l}\text { Dummy variable that equals } 1 \text { if } \\
\text { respondent's highest educational } \\
\text { level attained was "Completed } \\
\text { (compulsory) elementary educa- } \\
\text { tion" }\end{array}$ & 0.13 & 0.34 & 0 & 1 \\
\hline
\end{tabular}




\begin{tabular}{|c|c|c|c|c|c|}
\hline & Definition & Mean & SD & Min & Max \\
\hline Middle education & $\begin{array}{l}\text { Dummy variable that equals } 1 \text { if } \\
\text { respondent's highest educa- } \\
\text { tional level attained was either } \\
\text { "Incomplete secondary school: } \\
\text { technical/vocational type/(Com- } \\
\text { pulsory) elementary education } \\
\text { and basic vocational qualifica- } \\
\text { tion", "Complete secondary } \\
\text { school: technical/vocational } \\
\text { type/Secondary, intermedi- } \\
\text { ate vocational qualification", } \\
\text { "Incomplete secondary: } \\
\text { university-preparatory type/ } \\
\text { Secondary, intermediate general } \\
\text { qualification" or "Complete sec- } \\
\text { ondary: university-preparatory } \\
\text { type/Full secondary, maturity } \\
\text { level certificate" }\end{array}$ & 0.54 & 0.50 & 0 & 1 \\
\hline Higher education & $\begin{array}{l}\text { Dummy variable that equals } 1 \text { if } \\
\text { respondent's highest educational } \\
\text { level attained was either "Some } \\
\text { university without degree/higher } \\
\text { education-lower-level tertiary } \\
\text { certificate" or "University with } \\
\text { degree/higher education- } \\
\text { upper-level tertiary certificate" }\end{array}$ & 0.25 & 0.43 & 0 & 1 \\
\hline Income & $\begin{array}{l}\text { Respondent's positioning of his } \\
\text { household's income on a scale } \\
\text { ranging from } 1 \text { (=lowest income } \\
\text { group) to } 11 \text { (=highest income } \\
\text { group). The scale refers to his } \\
\text { country. The respondent was } \\
\text { asked to take into account all } \\
\text { wages, salaries, pensions and } \\
\text { other incomes of his household }\end{array}$ & 4.95 & 2.18 & 1 & 10 \\
\hline \multicolumn{6}{|c|}{$\begin{array}{l}\text { Social class (excluded category: } \\
\text { working class) }\end{array}$} \\
\hline Middle class & $\begin{array}{l}\text { Dummy variable that equals } 1 \text { if } \\
\text { respondent described himself as } \\
\text { belonging to the middle class }\end{array}$ & 0.56 & 0.50 & 0 & 1 \\
\hline Upper class & $\begin{array}{l}\text { Dummy variable that equals } 1 \text { if } \\
\text { respondent described himself as } \\
\text { belonging to the upper class }\end{array}$ & 0.02 & 0.14 & 0 & 1 \\
\hline \multicolumn{6}{|c|}{$\begin{array}{l}\text { Political position (excluded cat- } \\
\text { egory: political center) }\end{array}$} \\
\hline Political left & $\begin{array}{l}\text { Dummy variable that equals } 1 \text { if } \\
\text { respondent described his views } \\
\text { as left-wing }\end{array}$ & 0.15 & 0.36 & 0 & 1 \\
\hline Political right & $\begin{array}{l}\text { Dummy variable that equals } 1 \text { if } \\
\text { respondent described his views } \\
\text { as right-wing }\end{array}$ & 0.25 & 0.43 & 0 & 1 \\
\hline
\end{tabular}




\begin{tabular}{|c|c|c|c|c|c|}
\hline & Definition & Mean & SD & Min & $\operatorname{Max}$ \\
\hline Postmaterialist & $\begin{array}{l}\text { Postmaterialist index } 12 \text {-item, } \\
\text { scaled to range from } 0 \text { (material- } \\
\text { ism }[\mathrm{M}] \text { ) to } 1 \text { (postmaterialism } \\
\text { [PM]). The index is based on } \\
\text { how important respondents } \\
\text { think the following } 12 \text { items } \\
\text { are: (1) Maintaining a high level } \\
\text { of economic growth [M]. (2) } \\
\text { Making sure this country has } \\
\text { strong defense forces [M]. (3) } \\
\text { Seeing that people have more to } \\
\text { say about how things are done at } \\
\text { their jobs and in their communi- } \\
\text { ties [PM]. (4) Trying to make } \\
\text { our cities and countryside more } \\
\text { beautiful [PM]. (5) Maintaining } \\
\text { order in the nation [M]. (6) Giv- } \\
\text { ing people more say in impor- } \\
\text { tant government decisions [PM]. } \\
\text { (7) Fighting rising prices [M]. } \\
\text { (8) Protecting freedom of speech } \\
\text { [PM]. (9) A stable economy } \\
\text { [M]. (10) Progress toward a less } \\
\text { impersonal and more humane } \\
\text { society [PM]. (11) Progress } \\
\text { toward a society in which ideas } \\
\text { count more than money [PM]. } \\
\text { (12) The fight against crime [M] }\end{array}$ & 0.40 & 0.23 & 0 & 1 \\
\hline \multicolumn{6}{|c|}{$\begin{array}{l}\text { Religion adherence (excluded } \\
\text { category: non-religious) }\end{array}$} \\
\hline Protestant & $\begin{array}{l}\text { Dummy variable that equals } 1 \text { if } \\
\text { respondent adhered to Protes- } \\
\text { tantism }\end{array}$ & 0.16 & 0.37 & 0 & 1 \\
\hline Roman Catholic & $\begin{array}{l}\text { Dummy variable that equals } 1 \text { if } \\
\text { respondent adhered to Roman } \\
\text { Catholicism }\end{array}$ & 0.25 & 0.43 & 0 & 1 \\
\hline Eastern Orthodox & $\begin{array}{l}\text { Dummy variable that equals } 1 \text { if } \\
\text { respondent adhered to Eastern } \\
\text { Orthodoxy }\end{array}$ & 0.15 & 0.36 & 0 & 1 \\
\hline Other Christian & $\begin{array}{l}\text { Dummy variable that equals } 1 \\
\text { if respondent adhered to a Chris- } \\
\text { tian religion other than Roman } \\
\text { Catholicism, Protestantism and } \\
\text { Eastern Orthodoxy }\end{array}$ & 0.02 & 0.14 & 0 & 1 \\
\hline Jewish & $\begin{array}{l}\text { Dummy variable that equals } 1 \text { if } \\
\text { respondent adhered to Judaism }\end{array}$ & 0.00 & 0.05 & 0 & 1 \\
\hline Muslim & $\begin{array}{l}\text { Dummy variable that equals } 1 \text { if } \\
\text { respondent adhered to Islam }\end{array}$ & 0.15 & 0.36 & 0 & 1 \\
\hline Hindu & $\begin{array}{l}\text { Dummy variable that equals } 1 \text { if } \\
\text { respondent adhered to Hinduism }\end{array}$ & 0.02 & 0.13 & 0 & 1 \\
\hline Buddhist & $\begin{array}{l}\text { Dummy variable that equals } 1 \\
\text { if respondent adhered to Bud- } \\
\text { dhism }\end{array}$ & 0.05 & 0.23 & 0 & 1 \\
\hline
\end{tabular}




\begin{tabular}{|c|c|c|c|c|c|}
\hline & Definition & Mean & SD & Min & $\operatorname{Max}$ \\
\hline Other Eastern religions & $\begin{array}{l}\text { Dummy variable that equals } 1 \text { if } \\
\text { respondent adhered to an East- } \\
\text { ern religion other than Hinduism } \\
\text { and Buddhism }\end{array}$ & 0.00 & 0.02 & 0 & 1 \\
\hline Other religions & $\begin{array}{l}\text { Dummy variable that equals } 1 \text { if } \\
\text { respondent adhered to other reli- } \\
\text { gions than Christianity, Judaism, } \\
\text { Islam, Hinduism, Buddhism and } \\
\text { other Eastern religions }\end{array}$ & 0.03 & 0.18 & 0 & 1 \\
\hline God important & $\begin{array}{l}\text { Respondent's answer to the ques- } \\
\text { tion, "How important is God in } \\
\text { your life?" Scale from } 1 \text { (= Not } \\
\text { at all important) to } 10 \text { (= Very } \\
\text { important) }\end{array}$ & 7.74 & 2.94 & 1 & 10 \\
\hline Female & $\begin{array}{l}\text { Dummy variable that equals } 1 \text { if } \\
\text { respondent was female }\end{array}$ & 0.50 & 0.50 & 0 & 1 \\
\hline Age & Age of respondent in years & 45.45 & 14.53 & 25 & 97 \\
\hline $\mathrm{Age}^{2}$ & Age of respondent squared & 2276.99 & 1452.02 & 2625 & 9409 \\
\hline \multicolumn{6}{|c|}{$\begin{array}{l}\text { Ethnicity (excluded category: other } \\
\text { ethnicity) }\end{array}$} \\
\hline White & $\begin{array}{l}\text { Dummy variable that equals } 1 \\
\text { if respondent's ethnicity was } \\
\text { "White" }\end{array}$ & 0.49 & 0.50 & 0 & 1 \\
\hline Black & $\begin{array}{l}\text { Dummy variable that equals } 1 \\
\text { if respondent's ethnicity was } \\
\text { "Black" }\end{array}$ & 0.16 & 0.37 & 0 & 1 \\
\hline East Asian & $\begin{array}{l}\text { Dummy variable that equals } 1 \text { if } \\
\text { respondent's ethnicity was "East } \\
\text { Asian" }\end{array}$ & 0.03 & 0.17 & 0 & 1 \\
\hline Other Asian or Arab & $\begin{array}{l}\text { Dummy variable that equals } 1 \\
\text { if respondent's ethnicity was } \\
\text { "Other Asian or Arab" }\end{array}$ & 0.18 & 0.38 & 0 & 1 \\
\hline Health & $\begin{array}{l}\text { Respondent's answer to the ques- } \\
\text { tion, "All in all, how would you } \\
\text { describe your state of health } \\
\text { these days?" Scale: } 1=\text { very } \\
\text { poor, } 2=\text { poor, } 3=\text { fair, } 4=\text { good, } \\
5=\text { very good }\end{array}$ & 3.86 & 0.84 & 1 & 5 \\
\hline \multicolumn{6}{|c|}{$\begin{array}{l}\text { Marital status (excluded category: } \\
\text { single) }\end{array}$} \\
\hline Married & $\begin{array}{l}\text { Dummy variable that equals } 1 \text { if } \\
\text { respondent was married }\end{array}$ & 0.60 & 0.49 & 0 & 1 \\
\hline Living together & $\begin{array}{l}\text { Dummy variable that equals } 1 \\
\text { if respondent lived together as } \\
\text { married }\end{array}$ & 0.10 & 0.30 & 0 & 1 \\
\hline Divorced & $\begin{array}{l}\text { Dummy variable that equals } 1 \text { if } \\
\text { respondent was divorced }\end{array}$ & 0.05 & 0.22 & 0 & 1 \\
\hline Separated & $\begin{array}{l}\text { Dummy variable that equals } 1 \text { if } \\
\text { respondent was separated }\end{array}$ & 0.03 & 0.16 & 0 & 1 \\
\hline Widowed & $\begin{array}{l}\text { Dummy variable that equals } 1 \text { if } \\
\text { respondent was widowed }\end{array}$ & 0.07 & 0.25 & 0 & 1 \\
\hline Children & $\begin{array}{l}\text { The respondent's number of } \\
\text { children }\end{array}$ & 2.06 & 1.62 & 0 & 8 \\
\hline
\end{tabular}




\begin{tabular}{|c|c|c|c|c|c|}
\hline & Definition & Mean & SD & Min & $\operatorname{Max}$ \\
\hline Family important & $\begin{array}{l}\text { Dummy variable that equals } 1 \text { if } \\
\text { respondent said that family was } \\
\text { very important or rather impor- } \\
\text { tant in his life. It equals } 0 \text { if he } \\
\text { said that family was not very } \\
\text { important or not at all important }\end{array}$ & 0.99 & 0.11 & 0 & 1 \\
\hline \multicolumn{6}{|c|}{$\begin{array}{l}\text { Employment status (excluded } \\
\text { category: non-employed) }\end{array}$} \\
\hline Employed & $\begin{array}{l}\text { Dummy variable that equals } 1 \\
\text { if respondent was employed } \\
\text { (full time, part time or self- } \\
\text { employed) }\end{array}$ & 0.62 & 0.49 & 0 & 1 \\
\hline Unemployed & $\begin{array}{l}\text { Dummy variable that equals } 1 \text { if } \\
\text { respondent was unemployed }\end{array}$ & 0.09 & 0.29 & 0 & 1 \\
\hline Town & $\begin{array}{l}\text { Size of town in which respond- } \\
\text { ent lived. Scale ranging from } 1 \\
(=\text { under } 2000) \text { to } 8(=500,000 \\
\text { and more })\end{array}$ & 4.67 & 2.54 & 1 & 8 \\
\hline GDP per capita & $\begin{array}{l}\text { Natural logarithm of real GDP } \\
\text { per capita in } 2011 \text { US dollar at } \\
\text { purchasing power parity }\end{array}$ & 9.39 & 0.95 & 6.64 & 10.74 \\
\hline Democracy & $\begin{array}{l}\text { Index measuring the degree of } \\
\text { autocracy/democracy based on } \\
\text { the competitiveness and regula- } \\
\text { tion of political participation, } \\
\text { the openness and competitive- } \\
\text { ness of executive recruitment } \\
\text { and the constraints on the } \\
\text { chief executive. It ranges from } \\
0 \text { (strongly autocratic) to } 1 \\
\text { (strongly democratic) }\end{array}$ & 0.81 & 0.24 & 0.15 & 1.00 \\
\hline Civil liberties & $\begin{array}{l}\text { Index measuring the extent } \\
\text { of civil liberties, including } \\
\text { religious, ethnic, economic, } \\
\text { linguistic, gender and family } \\
\text { rights, personal freedoms and } \\
\text { freedom of the press, belief } \\
\text { and association. The index is } \\
\text { scaled to range from } 0 \text { to } 1 \text {, with } \\
\text { higher values representing more } \\
\text { civil liberties (or more respect } \\
\text { for or more protection of civil } \\
\text { liberties) }\end{array}$ & 0.71 & 0.26 & 0.17 & 1.00 \\
\hline Free choice & $\begin{array}{l}\text { How much freedom of choice and } \\
\text { control respondents feel to have } \\
\text { over the way their lives turns } \\
\text { out. Respondent's positioning on } \\
\text { a } 10 \text {-point scale from } 1 \text { (=none } \\
\text { at all) to } 10 \text { (=a great deal) }\end{array}$ & 7.20 & 2.21 & 1 & 10 \\
\hline Private credit & $\begin{array}{l}\text { The financial resources provided } \\
\text { to the private sector by deposit } \\
\text { money banks and other financial } \\
\text { institutions as a decimal fraction } \\
\text { of GDP }\end{array}$ & 0.63 & 0.50 & 0.10 & 2.37 \\
\hline
\end{tabular}




\begin{tabular}{llllll}
\hline & Definition & Mean & SD & Min & Max \\
\hline Trust & $\begin{array}{l}\text { Dummy variable that equals 1 if } \\
\text { respondent said that, generally } \\
\text { speaking, most people can be }\end{array}$ & & & & \\
& trusted. It equals 0 if he said \\
& that, generally speaking, you \\
& need to be very careful in deal- \\
& ing with people & & & \\
& & & & \\
& & & \\
\end{tabular}

The data are from World Values Survey waves 5 (2005-2009) and 6 (2010-2014) (Inglehart et al. 2015), except for 'economic freedom', Gwartney et al. (2019); 'GDP per capita', Feenstra et al. 2019); 'democracy', Marshall et al. (2017); 'civil liberties', Freedom House (2019) and 'private credit', World Bank (2018a).

\section{Appendix 2: List of countries}

Algeria, Armenia, Australia, Azerbaijan, Brazil, Bulgaria, Burkina Faso, Canada, Chile, Colombia, Cyprus, Ecuador, Estonia, Ethiopia, Germany, Ghana, Hungary, India, Indonesia, Italy, Kazakhstan, Kyrgyzstan, Lebanon, Malaysia, Mali, Mexico, Moldova, Morocco, Netherlands, New Zealand, Nigeria, Peru, Philippines, Poland, Romania, Russia, Rwanda, Serbia and Montenegro, South Africa, Sweden, Thailand, Trinidad and Tobago, Tunisia, Ukraine, Uruguay, Vietnam, Zambia, Zimbabwe.

\section{References}

Acar, E. (2011). Effects of social capital on academic success: A narrative synthesis. Educational Research and Reviews, 6(6), 456-461.

Berggren, N., \& Jordahl, H. (2006). Free to trust: Economic freedom and social capital. Kyklos, 59(2), $141-169$.

Berggren, N., \& Nilsson, T. (2013). Does economic freedom foster tolerance? Kyklos, 66(2), 177-207.

Coleman, J. S. (1988). Social capital in the creation of human capital. American Journal of Sociology, 94, S95-S120.

Croll, P., Attwood, G., Fuller, C., \& Last, K. (2008). The structure and implications of children's attitudes to school. British Journal of Educational Studies, 56(4), 382-399.

Davis-Kean, P. E. (2005). The influence of parent education and family income on child achievement: The indirect role of parental expectations and the home environment. Journal of Family Psychology, 19(2), 294-304.

Day Ashley, L., et al. (2014). The role and impact of private schools in developing countries: A rigorous review of the evidence. London: Department for International Development.

De Gregorio, J. (1996). Borrowing constraints, human capital accumulation, and growth. Journal of Monetary Economics, 37(1), 49-71.

Feenstra, R. C., Inklaar, R., \& Timmer, M. P. (2019). Penn World Table 9.1. Retrieved April 12, 2019, from https://www.rug.nl/ggdc/productivity/pwt/.

Feldmann, H. (2017). Economic freedom and human capital investment. Journal of Institutional Economics, $13(2), 421-445$.

Feldmann, H. (2020). Who favors education? Insights from the World Values Survey. Comparative Sociology, 19(4-5), 509-541.

Fladmoe, A. (2012). Mass political polarization and attitudes towards education as part of the welfare state in Norway, Sweden and Finland. Journal of European Social Policy, 22(1), 45-62.

Freedom House. (2019). Freedom in the world 2019. Retrieved February 8, 2019, from https://freedomhou se.org. 
Galor, O., \& Zeira, J. (1993). Income distribution and macroeconomics. Review of Economic Studies, 60(1), 35-52.

Gorman, T. J. (1998). Social class and parental attitudes toward education: Resistance and conformity to schooling in the family. Journal of Contemporary Ethnography, 27(1), 10-44.

Gwartney, J., Lawson, R., Hall, J., \& Murphy, R. (2019). Economic freedom of the world: 2019 annual report. Vancouver, B.C.: Fraser Institute.

Hall, J. C., \& Lawson, R. A. (2014). Economic freedom of the world: An accounting of the literature. Contemporary Economic Policy, 32(1), 1-19.

Hanushek, E. A., \& Woessmann, L. (2015). The knowledge capital of nations: Education and the economics of growth. Cambridge, MA: MIT Press.

Hastings, J. S., Kane, T. J., \& Staiger, D. O. (2006). Parental preferences and school competition: Evidence from a public school choice program, NBER Working Paper No. 11805. Cambridge, MA: NBER.

Hoover-Dempsey, K. V., \& Sandler, H. M. (1997). Why do parents become involved in their children's education? Review of Educational Research, 67(1), 3-42.

Inglehart, R. F., et al. (2015). World Values Survey. Longitudinal data (1981-2014). Retrieved June 27, 2017, from https://www.worldvaluessurvey.org.

Jacob, B. A., \& Lefgren, L. (2007). What do parents value in education? An empirical investigation of parents' revealed preferences for teachers. Quarterly Journal of Economics, 122(4), 1603-1637.

King, E. M., Montenegro, C. E., \& Orazem, P. F. (2012). Economic freedom, human rights, and the returns to human capital: An evaluation of the Schultz hypothesis. Economic Development and Cultural Change, 61(1), 39-72.

Lipset, S. M. (1960). Political man: The social bases of politics. Garden City, NY: Doubleday.

Long, J. S. (1997). Regression models for categorical and limited dependent variables. Thousand Oaks, CA: Sage.

Marshall, M. G., Gurr, T. R., \& Jaggers, K. (2017). Polity IV project: Political regime characteristics and transitions, 1800-2017, version 2017. Retrieved January 31, 2019, from https://www.systemicpeace. org.

McFadden, D. (1973). Conditional logit analysis of qualitative choice behavior. In P. Zarembka (Ed.), Frontiers in econometrics (pp. 105-142). New York: Academic Press.

McKelvey, R. D., \& Zavoina, W. (1975). A statistical model for the analysis of ordinal level dependent variables. Journal of Mathematical Sociology, 4(1), 103-120.

Miller, T., Kim, A. B., Roberts, J. M., \& Tyrrell, P. (2020). 2020 Index of economic freedom. Washington, D.C.: Heritage Foundation.

Okulicz-Kozaryn, A. (2014). 'Freedom from' and ‘freedom to' across countries. Social Indicators Research, $118(3), 1009-1029$.

Spera, C., Wentzel, K. R., \& Matto, H. C. (2009). Parental aspirations for their children's educational attainment: Relations to ethnicity, parental education, children's academic performance and parental perceptions of school climate. Journal of Youth and Adolescence, 38(8), 1140-1152.

Teague, M. V., Storr, V. H., \& Fike, R. (2020). Economic freedom and materialism: An empirical analysis. Constitutional Political Economy, 31, 1-44.

Tooley, J. (2013). The beautiful tree: A personal journey into how the world's poorest people are educating themselves. Washington, D.C.: Cato Institute.

Veall, M. R., \& Zimmermann, K. F. (1996). Pseudo-R2 measures for some common limited dependent variable models. Journal of Economic Surveys, 10(3), 241-259.

Woessmann, L. (2016). The importance of school systems: Evidence from international differences in student achievement. Journal of Economic Perspectives, 30(3), 3-32.

World Bank. (2018a). Global financial development database. Retrieved October 8, 2019, from https://data. worldbank.org.

World Bank. (2018b). Human capital index. Retrieved February 25, 2020, from https://databank.worldbank. org.

Publisher's Note Springer Nature remains neutral with regard to jurisdictional claims in published maps and institutional affiliations. 